\title{
Cultural Diplomacy Strategies: Looking into Korean Entertainment Company SM Entertainment
}

\author{
S M Deniar ${ }^{1}$, T D Effendi², S D Kusuma ${ }^{3}$ \\ 1,2,3 Universitas Muhammadiyah Malang \\ \{shannazdeniar@umm.ac.id ${ }^{1}$,tonny@umm.ac.id², sdk111996@gmail.com³
}

\begin{abstract}
The purpose of this study is examined the cultural diplomacy strategies on one of the Korean biggest entertainment company, SM Entertainment. Looking into the growth of Korean Wave, SM Entertainment which established in 1995 have discovered and produced many K-Pop celebrities. Through their efficient business strategy, the company has developed its product in the domestic and global market significantly. As one of the agent of cultural diplomacy, this research will focus on answering how is the strategies of SM Entertainment through the Korean Wave. The result of this research found that SM Entertainment has developed their cultural diplomacy strategies by creating a unique point of competitiveness and interesting content which lead to the image branding of Korean Popular Culture overseas.
\end{abstract}

Keywords: SM Entertainment, Cultural Diplomacy, Korean Wave, South Korea.

\section{INTRODUCTION}

The word hallyu came from Chinese character 'hanliu' literally meaning as Korean (cultural) wave or current. for the past two decades, Korean Wave phenomena have been gained popularity in China, Hong Kong, Japan, South East Asia, and Europe. In 1995, the Government of South Korea issued a Motion Picture Promotion Law that became a major force in music and film export of South Korea. The government also increased the budget allocation to develop this sector. Then in 1998 under President Kim Daejung, who calls himself President of Culture, affirms the Basic Law for the Cultural Industry Promotion which has delivered several program such as Asia Song Festival where South Korea invites a number of performers from several countries in Asia to hold the concert together. His goal was to improve the foreign tourists to South Korea.

The effort from the government bring result in the development of cultural product such as Korean drama or TV series which later named as the first era of Hallyu or Hallyu 1.0 [1]. Hallyu 1.0 presented in the popularity of K-Drama in Japan and China in the late 1990s. The popularity of K-Drama 'What is Love About' followed by the huge success of Bae Yong Jun's Winter Sonata in Japan and sageuk- historical period- drama The Great Jang Geum which later exported to 91 countries. Korean pop culture received a big success not only in neighbor country but also in Southeast Asian countries such as Vietnam, Thailand, and Singapore. Between 1997 and 2000 there was more than 60 Korean drama played in Vietnamese television. The growth of new media outlets such as Youtube, Facebook, and other social media platform become a significant point of Hallyu 2.0. Through those platforms, young people in Asia, North America, and Europe beginning to appeal by the vibrant and energetic 
music, K-Pop, and it became compelling of the new form of Korean Wave or known as shinHallyu or New Korean Wave (Hallyu 2.0). The increasing number of debuted Idol group initiated the new Korean Wave syndrome which we know now. The rise of K-Pop (Korean Pop) as a new genre in global music continuing to remain popular not just in Asia but worldwide.

South Korea became one of the countries that succeeded in running the cultural diplomacy by using and promoting the cultural products that are owned as a form of their new strength. South Korea began to spread and promote their own culture such in movies, drama series, online games, fashion, music and food as a form of official government policy in South Korea to help improve the economy. The phenomenon of the Korean Wave has been able to increase the tourists who come to Korea by $30 \%$ in 2000; the travelers make a visit to the shooting location of the drama or film when they visited the country. In the category of selling local goods such as cosmetics, online games, fashion items and souvenirs, the Korean wave accounted for $\$ 918$ billion. With many celebrities (boy group, girl group, bands, solo, actor and actress) make revenue from entertainment sector with totals 997.3 billion won; the export value of film, drama and music of 48.5 billion won and absorbed 78,730 labour from this sector only [2]. South Korea government recognizes that the increased interest in popular culture is very profitable for the country.

Major entertainment company have discovered and produces many celebrities who become the center of Korean Wave. SM Entertainment, JYP Entertainment, and YG Entertainment, the "Big 3" of the South Korean entertainment industry, were valued at USD 772 million, USD 516 million, and USD 498 million respectively in January 2018 [3]. SM Entertainment which established in 1995 by Lee Sooman was operating as a record label and music production companies, concert, event management and music publishing house. SM Entertainment also operates in other countries, such as SM Entertainment Japan, USA, China, Thailand and also in Indonesia.

Almost 25 years since Lee Sooman founded SM Entertainment, the success of this enterprise is inseparable from the cultural diplomacy strategy to which they apply. The company regularly renews its business strategy for expanding market as well as create unique content and quality in accordance with the wishes of the market that is constantly changing from time to time to disseminate popular culture through the Korean Wave . To analyze it, this research will elucidate the artist development system, joint ventures and marketing undertaken by the company to get a conclusion how cultural diplomacy strategy of the company in the development of Korean Wave not only in Asia but also in the whole world.

\subsection{Research Method}

This research used a qualitative method with a case study approach. Furthermore, collecting evidence and producing findings will be conducted to explore in depth and make a comprehensive description of an event, activity, and process The data collection technique used study of literature includes books, news and articles, paper, online literature, and other sources with regards to the topic of entertainment industry particularly SM Entertainment strategy business from time to time and its effect on the cultural diplomacy through the Korean Wave. Documentation, archival records, and audio-visual material also used as complementary. 


\subsection{Result and Discussion}

Cultural diplomacy is defined as the effort of a country to fight for the interests of the nation through the cultural dimension, whether micro such as through education, the arts, science or in a macro for example by propaganda not shaped by the political, economic, or military [4]. In diplomacy, we can find a soft power, branding, propaganda, or public diplomacy. The cultural diplomacy is located on the side of soft power which its functions lies not in coercion but on interest and understanding. Cultural diplomacy also talks about art, education or Language which are universal so that it attracts people more closely. Cultural diplomacy can be in the form of an exchange of ideas, information, art and cultural aspects among Nations that may give rise to mutual understanding [5].

In contrast to public diplomacy that is unilaterally, cultural diplomacy using bilateral or multilateral approaches. In terms of the offender or the actor who can do the activities of cultural diplomacy could have been done by the Government or non-government institution, individual or collective, or every citizen. Purpose i.e. affect public opinion in other countries of the community. The main target of cultural diplomacy is public opinion which can affect the behavior of the community of a nation State is not just by the government only. So the characteristic pattern of communication is more emphasized and not on the field of operation. Through cultural diplomacy, we seek to understand the views of others to see similarities and differences.

Korean Wave as a mass popular culture is a global phenomenon that describe changes either the scale or the effect. A new genre of music K-Pop is a blend of Western music genres (hip hop, pop) served with a touch of Korea through catchy lyrics and unique choreography. The development of technology such as fast internet access also utilized by the actors to expand the scope of popular culture wave of South Korea. As an entertainment company, SM Entertainment has had enough of the great participation as actor in South Korea cultural diplomacy be involved in the dissemination of Korean Wave to build the country image. To analyze the cultural diplomacy strategy of this company, this research will pointed out several strategic points of company's artist development system and categorized it to get the conclusion how it spread the branding image of Korean Wave.

As mentioned above, the rise of K-Pop (Korean Pop) as the new genre in the global music also named as the beginning of Shin Hallyu or the New Korean Wave. But it need to be mentioned that SM Entertainment has started this phenomena in the 1990s which later followed by other companies such as JYP Entertainment (1997) and YG Entertainment (1998). SM Entertainment has laid the foundation of the modern idol training system in South Korea. Lee Sooman was inspired by the training system in Japan, especially by Johnny's Jimusho. The new system should be created to ensuring the process of creating, producing, and promoting be compelled to the character and image of the artist. All of the necessary attributes are needed to create the perfect pop star. As a result, SM Entertainment held auditions not only in Korea but also outside of the country to look for a young talented artist. After they got selected, the young talented man were brought to be trained intensively not just in singing and dancing but also get acting, language class, personality, and public behavior class. In 1996, SM Entertainment debuts their first idol group formed by five young multitalented men, known as H.O.T (High-five Of Teenagers), modeled after the Japanese idol group SMAP. H.O.T received a huge amount of success, their debut album selling 1.5 million copies. In total, H.O.T has sold over 12 million albums and singles domestically and overseas, with relatively short activities as idol group when they later decided to disband in 2001. 
The popularity of these idol group proven that SM Entertainment has successfully manufactured their New Pop Star training system. This system gives insurance for an entertainment company to get something in return later. This so-called in-house production system needs a guarantee that their final product can be sold and befitting with market demand [6]. As a product, the trainee gets training not only for their talent in singing, dancing, and acting but they also learning languages, presenting on camera, public speaking, culture education and many more [7]. The training period varies from several months to several years. Kangta, member of H.O.T got trained almost 3 years before debuting, different with Bada, member of SES, got recruited when Lee Soo Man saw her singing at her school in 1996 and debuting in less than one year in 1997. SM Entertainment not only as an artist management company but also producing a new talented artist with full packages. The entertainment companies prefer to debut new artists in groups rather than soloist is also seen as a strategic choice. To train a group is less expensive than just training a soloist. An idol group contains many individuals who have their own appeal to attract fans, each individual also has a different image, roles or talent [6]. Like other companies that do not produce only one homogeneous product but also to meet different national market targets. For example, duo vocalist Fly to the Sky member, Brian Joo and Hwanhee has a different role, Brian Joo was born in Korea but living in the US, he is fluent in English with good vocal abilities that can reach non-Korean fans.

Following the success of their artist, periodically SM Entertainment debuting several idol group names such as TVXQ (2003), Super Junior (2005), Girls Generation (2007), SHINee (2008), and $\mathrm{F}(\mathrm{x})$ (2009). In accordance with the in house production system that they have, each member of this idol group undergoes a similar process from casting and heavy burden training process to find the best candidates who are ready to debut. At the casting stage, the company sought out the new talents through auditions in both domestically and abroad such as China, Thailand, and America. The training process is an investment made by the company to producing multi-talented artist. Every trainee assessed through periodic evaluations that are quite competitive. The duration of training is very different, Leeteuk members from Super Junior took 5 years to finally debut. As a result of intensive training, the content that is presented is quite a difference compared to other artists. The content includes music, dance, and visuals. Each idol group has its own uniqueness. K-Pop stars can quickly get a special place in the hearts of the fans because the products they offer are complete ranging from vocal techniques, dance skills, and attractive appearances and styles.

In the process of producing the music, SM Entertainment has a strategy that is quite different through the process of outsourcing creativity by working with top experts in the fields of music, performance, and choreography [7]. Girls Generation's hit song Genie was composed by Design Group from Europe, Yu Yeong-jin, SM's producer, writes the lyrics and arrangement, and the dance choreography created by Rino Nakashi Razalan. Promotions conducted by SM Entertainment focused on gaining recognition from global customers. Therefore, SM Entertainment collaborates with overseas partners. For example in Japan, SM collaborated with Sony Music Japan and Avex Trax in the process of recording and promotion. This is done to get closer to the local market. For example, the idol group TVXQ has a stage name in Japan named Tohoshinki. Tohoshinki is quite popular in Japan apart from being capable of skill, they are also fairly close to the Japanese public because of their fluency in Japanese. During promotions in Japan, they performed songs in Japanese. The idol group Super Junior also conducts promotional activities in China under another name, Super JuniorM. Super Junior is the first SM Entertainment idol group to have other citizenship members, Hangeng is a Chinese. 
The success of the SM Entertainment idol group also depends on the development of information technology through several social media platforms such as Youtube, Facebook, and Twitter [8]. Girls Generation immediately ranked first on the Oricon Chart at the beginning of its debut in Japan in 2011, in contrast to senior Tohoshinki who needed around four years to make an impression. When Youtube launched in 2005, the dissemination of music video has increased and become the intermediate of K-Pop and the whole music industry in Korea. The social media also the new communicating tools between fans. The spread of K-Pop through social media is assisted by their consumers who are mostly young people, the target marketer of Hallyu 2.0 [9]. They are very aware and active in information technology. K-Pop stars also communicate directly with their fans through social media. A catchy song sung by talented and charming visual also with the fans as a consumer give opportunities for a company like SM Entertainment to create new products and marketing strategies to boost sales of new product development such as online games, movie, cosmetic brand, and tour package [6] [9].

In a press conference for SM Town Concert in Paris 2011, Lee Soo Man explained the concept of the Cultural Technology used by SM Entertainment so far [10]. Cultural technology has been used to explain a system used by the agencies to manufacture, disseminate, and promote Korean cultural products to local and overseas consumer [11]. Lee explained the Artist Development System consisting of several processes, such as Casting, Training, Marketing / Management and Producing. In terms of casting, SM still uses a system that has been implemented since 1995. The audition process has been carried out in more than 20 cities in the world. Then, the training process undertaken by trainees is also continuously adapted to the times. Furthermore, in the process of music production also related to cultural technology, SM Entertainment uses its Internal Producing System which focused on differentiation of the content to create trends. This trend is not only in music but also in costumes, choreography and music videos. This process also integral to outsource production. In the management artist, SM Entertainment is not only a talent agency of idol groups but also actors/actresses, MCs, and sportsmen. SM Entertainment also producing several drama and reality show. Not a little that idol member becomes an MC or actor in the drama. Heechul, debuted in Super Junior now actively join in several variety shows. Using idol to be the main star at such a show, can help with the viewer rating.

The South Korea government has focused on cultural technology to promoting Korean cultural product since the 1990s, using dramas and K-Pop music as export product and also to control the image of the country. Several government institutions also promote K-Pop culture on an international level. The government used SM Entertainment artist, for example, Girls Generation as the Korea Tourism Ambassador, idol group EXO performs at 2014 Incheon Asian Games. Not only that but SM Entertainment also regularly engaged with several project philanthropy. In 2011, SM Entertainment donated \$100,000 USD to the Center Culturel Coreen in Paris to raise awareness of Korean culture to the French public. SM artist also held two days concert in Paris. Entertainment companies also promote tourism, SM Entertainment join hands with Korail (Korea Railroad Corporation) to promote 'Hallyu tourism'.

In 2016, Lee Soo Man introduced the New Cultural Technology [12], with keyword 'interactive', to communicate and interact with all, he explained SM Entertainment's future project such as first, established an electronic dance music (EDM) label and will hold annual EDM music festival. second, SM Entertainment will launch a smartphone application, the user can engage in producing music and video by themselves. third, new form digital music channel, STATION, a collaboration of SM Entertainment with other label artists, producer, composer, and company's brand. fourth, launch the Rookies Entertainment Mobile Application 
to experience the SM Star Incubating System, also provides an opportunity for an internship at the company.

\section{CONCLUSIONS}

The major entertainment company, SM Entertainment business strategy developed to meet with the market demand. SM Entertainment first introduced the new training system to produce a new K-Pop star. With the development of technology, SM Entertainment using social media platform as their distribution tools. To improve the efficiency, the company using the cultural technology concept, teaming up with local companies to create a joint venture. And the latest is the Hallyu Localization which transferred SM's new cultural technology to the local market. With a comprehensive strategy, SM Entertainment was able to create a unique point of competitiveness and interesting content based on the changing in market demand which helped the country's image through their cultural diplomacy strategy.

\section{REFERENCES}

[1] K. Bok-rae, "Past, Present and Future of Hallyu (Korean Wave)," Am. Int. J. Contemp. Res., vol. 5, no. 5, p. 7, 2015.

[2] S. Chen, "Cultural technology: A framework for marketing cultural exports - analysis of Hallyu (the Korean wave)," Int. Mark. Rev., vol. 33, no. 1, pp. 25-50, Feb. 2016.

[3] M. J. Russell, Pop Goes Korea: Behind the Revolution in Movies, Music, and Internet Culture. Stone Bridge Press, 2012.

[4] Tulus Warsito, Diplomasi kebudayaan: konsep dan relevansi bagi negara berkembang: studi kasus Indonesia. Yogyakarta: Ombak, 2007.

[5] M. Cummings, "Cultural Diplomacy and the United States Government: A Survey," Am. Arts, p. 15, Jun. 2009.

[6] S. Min-Soo, "Lessons from K-pop's Global Success,” p. 7.

[7] G.-S. Park, "Manufacturing Creativity: Production, Performance, and Dissemination of K-pop,” KOREA J., vol. 53, no. 4, p. 20, 2013.

[8] I. Oh, "The Globalization of K-pop: Korea's Place in the Global Music Industry,” p. 12.

[9] J. Ahn, S. Oh, and H. Kim, "Korean pop takes off! Social media strategy of Korean entertainment industry," in 2013 10th International Conference on Service Systems and Service Management, Hong Kong, China, 2013, pp. 774-777.

[10] D. Yong Jin, "Hallyu 2.0: The New Korean Wave in the Creative Industry," Int. Inst. J., vol. 2, no. 1, Fall 2012.

[11] "What Business Can Learn from K-pop for Global Strategy - :: KOREA FOCUS ::" [Online]. Available: http://www.koreafocus.or.kr/design2/layout/content_print.asp?group_id=104017. [Accessed: 14-Feb-2019].

[12] J. Seabrook, "Factory Girls: Cultural technology and the making of K-pop," 01-Oct2012.

[13] "Entertainment firm finds future in Culture Technology," koreatimes, 31-Oct-2016. [Online]. Available: http://www.koreatimes.co.kr/www/art/2019/02/688_217157.html. [Accessed: 14-Feb-2019]. 